\title{
A VOLTA DO TERMO SURDOS-MUDOS: SOB UMA PERSPECTIVA CULTURAL E DE IDENTIDADE
}

\section{THE RETURN OF THE TERM DEAF-DUMB: UNDER A CULTURAL AND IDENTITY PERSPECTIVE}

\author{
Ana Regina e Souza Campello \\ Instituto Nacional de Educação de Surdos, INES, Rio de Janeiro, RJ, Brasil
}

\begin{abstract}
Resumo: O presente artigo trata da proposta de repensar a volta do uso dos conceitos e sentidos da designação: "Surdo-Mudo" Seu sentido e sua usurpaçăo da última palavra "Mudo", entretanto, foram bastantes influenciados pelas visóes positivista e estruturalista que modificaram o conceito, seu valor e sua cultura como instrumento de normalizaçáo (FOUCAULT, 2007). Em consequência, esse instrumento prescreveu como "apagamento do sujeito" (FOUCAULT, 2007 apud SCHOLZE, 2006). Historicamente, a criação da denominação "Surdo-Mudo" como palavra composta, surgiu durante a criação dos Direitos Civis no tempo do Imperador Justiniano. A designação Surdo-Mudo, para se referir aos sujeitos que não ouviam, bastavam as designaçóes "Surdo" ou "Mudo", em função do que se conhecia naquela época e se perpetuaram o uso de nome até o século XX. Usamos as abordagens de pesquisa na internet em caráter quantitativo quanto qualitativo. Segundo Batista (2012), estudos quantitativos utilizam-se basicamente das enquetes e questionários virtuais. Das pesquisas qualitativas, Flick (2009) cita a entrevista online, os grupos focais on-line, observação participante, cujo objetivo é aprofundar-se em cada um deles para apresentar a análise do resultado dos dados.
\end{abstract}

Palavras-chave: Surdo-Mudo, Historicidade, Conceito, Apagamento.

Abstract: This article is about the proposal and to rethink the return of the use of the concepts and meanings of the designation: "Deaf-Mute". Its meaning and its usurpation of the last word "Mute", however, was greatly influenced by the positivist and structuralist views that influenced the concept, its value and its culture as an instrument of normalization (FOUCAULT, 2007). As a result, this instrument was prescribed as "subject erasure" (FOUCAULT, 2007 apud SCHOLZE, 2006). Historically, the creation of the name "Deaf-Mute" as a compound word, which emerged during the creation of Civil Rights in the time of Emperor Justinian. The designation Deaf-Mute, to refer to subjects who did not hear, the designations "Deaf" or "Mute" were sufficient, depending on what was known at that time and the use of the name was perpetuated until the 20th century. We use internet research approaches in both quantitative and qualitative terms. According to Batista (2012), quantitative studies basically use virtual surveys and questionnaires. From qualitative research, Flick (2009) mentions the online interview, the online focus groups, participant observation, whose objective is to delve into each one of them to present the analysis of the data result.

Keywords: Deaf-Mute; Historicity; Concept; Erasure. 


\title{
1. Introduzindo a denominaçáo "Surdo-Mudo"
}

\begin{abstract}
"Todos aqueles que se tornaram crentes ficavam juntos e tinham tudo em comum; quem possuía propriedades e bens os vendia e dividia com todos, de acordo com as necessidades de cada um” Bíblia Sagrada, versão oficial CEI, 1999, Atos dos Apóstolos, 2, 44-45

Parafraseando: todos aqueles que se tornaram Surdos-Mudos ficavam juntos e tinham tudo em comum; quem possuía língua de sinais e cultura os ensinava e perseverava com todos, de acordo com as identidades de cada um.
\end{abstract}

Com base nos Estudos Culturais, a partir das releituras de Souza (2007), Silva (2000) e de Estudos Surdos, no campo brasileiro, com Perlin (2003), Skliar (1999), Quadros (1997) e outros, propomos repensar os conceitos e os sentidos da designação "Surdo-Mudo". Essa designação, inicialmente uma palavra composta, foi convertida para uma palavra, em função das mudanças ortográficas. Seu sentido, entretanto, foi bastante influenciado pelas visóes positivista e estruturalista que modificaram o conceito, seu valor e sua cultura como instrumento de normalizaçáo. Foucault (2007) cita que a normalização é baseada pela disciplina ao fazer funcionar a norma e a regra a partir de um sistema baseado na ideia de igualdade formal. Para tanto, a medida se realiza através de: comparação, diferenciação, hierarquização, homogeneização, exclusão e normalização. Em consequência, esse instrumento prescreveu o "apagamento do sujeito", que, segundo Lia Scholze (2006), refere-se àquilo que:

\footnotetext{
Não é o sujeito que produz o discurso, mas ele é resultado do entrecruzamento de discursos. Não é o sujeito por si que se expressa, porém ele é expresso por todas as narrativas que o constituem. Por sua voz falam as instituiçóes, os ensinamentos recebidos, os silenciamentos impostos, os discursos permitidos e os estimulados. Quem sou é o entrecruzamento das histórias que me narram e me constituem.
}

Outro elemento repressivo chamado assujeitamento da subjetividade, está ligado ao fato de que o sujeito nasce imerso em um sistema previamente estabelecido, mas movimento por mudanças. De acordo com Araldi (2005, p. 327):

Quando nasce, o indivíduo encontra à sua disposição um sistema de comunicaçáo estruturado e em constante desenvolvimento, do qual se apropria e com o qual interage. As primeiras articulaçóes são palavras desconexas, rapidamente corrigidas pelo adulto mais próximo. Quer dizer, 
ele não inventa um código linguístico para sua comunicação: apropria-se de um código já existente para, através dele, estabelecer comunicação com as pessoas e o meio que o cerca. Depara-se também com valores éticos e morais, crenças pessoais e religiosas, ideologias, etc. Tais condiçốes não são estáticas e separadas, coexistem agregando novas crenças e valores, fazendo com que o discurso seja naturalmente polifônico, ou seja, constituído de várias vozes que já o enunciaram em outra situação.

A isso podemos atrelar a ideia de pertença a uma identidade predeterminada e com posicionamento existencial que perdura desde o século passado: a denominação "Surdo-Mudo". Mas apesar do conceito "Surdo-Mudo" estar presente ao longo da história e sua constituição como povo ou nação "Surda-Muda" sempre ter existido, as denominaçôes SurdoMudo", "surdo" e "Deficiente Auditivo" possuem uma estrutura contextual que envolve um valor específico, um entrecruzamento nas transiçóes inter-Cultural transnacional ou do hibridismo e do colonialismo e/ou póscolonialismo. Percebemos aqui o quão embrincado está o conceito "SurdoMudo".

A introdução do conceito Surdo-Mudo não se apresenta somente como um termo corriqueiro no mundo de hoje, mas se trata de argumentamos, de uma referência afirmativa e não de submissão ou rejeição da pessoa Surda. A designação é antiga, porém foi submetida e atualizada em novas lógicas, em perspectivas diferentes. Ao nosso ver, como denominaçóes incorretas que violentam o direito humano da pessoa surda de sinalizar posicionando os surdos como sujeitos que precisam ser reparados por meio de recursos terapêuticos-medicinais. É óbvio que a denominação ainda é utilizada em certas áreas e divulgada nos meios de comunicação, principalmente na televisão, nos jornais e nas rádios, pela lógica de não ouvir e de não falar, mas se comunica com sinais. Defendemos que esse é uma política de denominação mais correta, pois enxerga a pessoa Surda como um ser afirmativo e náo como um ser estigmatizado. $O$ fato de uma pessoa ser Surda-Muda não significa que a voz dela seja muda. A voz é destoante por natureza da ausência de contato de som.

Desse modo, nos encontramos localizados num espaço de "entrelugar": por ser "Surdo-Mudo" um sujeito socialmente discriminado, colocado em uma situaçáo de não pertencimento em relação ao "NãoSurdo-Mudo". Todos esses entrelaçamentos da categoria "Surdo-Mudo" se

1Por "entre-lugar", Bhabha considera que seja "uma das elaboraçôes da estratégia de subjetivação - singular ou coletiva - que dáo início a novos signos de identidade e postos inovadores de colaboração e contestação, no ato de definir a própria idéia da sociedade.” (2005, p. 20). 
encontram atrelados à mentalidade provocada pelo surgimento da medicina que coincidiu com a instauração do Estado Liberal, positivista, antinatural ${ }^{2}$ e com o advento da revoluçáo industrial. A discriminaçáo da qual o surdomudo passou a ser vítima, o leva a "assumir" a interpretação artificial, cultural e filosófica da cultura do dominante-ocidental, o que desestrutura, simultaneamente, o valor e "verdade" do conceito essencial do Surdo-Mudo em relação à sua identidade. Tal fato provoca a necessidade desses sujeitos assujeitados de "aceitarem" as novas narrativas identitárias, não como pertença diferente do como ele é, mas como forma de sobrevivência e de defensiva ao mundo hostil e de economia selvagem.

O Surdo-Mudo, como sujeito que tem história e narrativa próprias, constitui a sua estrutura existencial: "Surdo-Mudo". Essa é uma designação muito comum, aceita e convencionada pela própria comunidade e até mesmo muito engajada por ser chamada pela designação dada. $\mathrm{O}$ sinal especificado que também se distingue o significado, tanto para Surdo-Mudo como para o Náo-Surdo-Mudo, é muito comumente aceito e convencionado pela comunidade Surda-Muda, de acordo com significado visual. No século passado até a presente data, o sinal de Surdo-Mudo é caracterizado pela ausência da audiçấo e da fala, conforme a Figura 1.

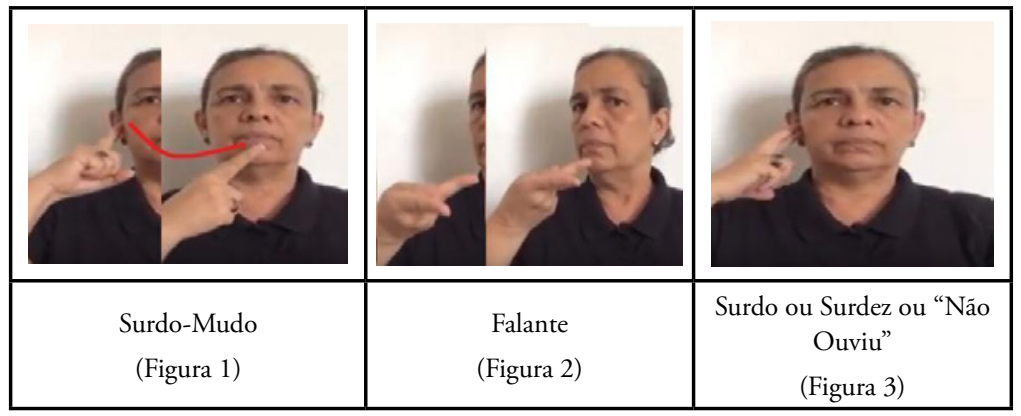

Importante ressaltar que por "mudo" náo se deve entender a impossibilidade de falar. $\mathrm{O}$ entendimento deve ser na direção do sentido de "que não fala porque não pode ouvir". Tomando por base a teoria de Derrida (1973), temos como foco a desconstruçáo da existência de um

\footnotetext{
${ }^{2}$ Antinatural porque a Língua de Sinais é uma língua natural e de modalidade viso-gestualespacial. A partir da revolução industrial, a natureza da pintura, poesia, educação ao ar livre, e a beleza dos movimentos das mãos foram suprimidos, perdendo, em si, o sentido e a essência, transformando mấo de obra barata e de massa, para poder produzir e competir no mundo da economia selvagem.
} 
fonocentrismo ${ }^{3}$, por meio do positivismo, que centraliza a importância da fala e a necessidade do artefato da audição para dar o significado ao ato de fala. Portanto, como forma de diferenciar, surgiu a representaçáo visual da comunidade Surda-Muda. Assim, a denominação "Surdo-Mudo" não significa que o sujeito surdo seja portador de "mudez", uma vez que a estrutura vocal está intacta. Também se encontra associada ao fato do sujeito não falar e sim por usar a língua de sinais, língua de modalidade viso-gestual e, portanto, não se faz necessário o uso da "fala" para articular e sim o ato de sinalizar.

Diferentemente do sinal do Não-Surdo-Mudo, do século passado, que era caracterizado pela "fala" (Figura 2), e que atualmente, em alguns estados do Brasil, foi modificado para "surdez" (Figura 3), todos esses fatos remontam ao positivismo e ao surgimento da proposta da filosofia oral, ocorrida durante o Congresso de Milão, quando o Surdo-Mudo foi submetido à terapia "imaginada" a partir da fala e da audição, referência do Não-Surdo-Mudo. Em consequência, por meio do avanço da medicina e com a influência dos dominantes sobre os dominados e assujeitados, nas palavras de Foucault, o sinal da "fala" foi modificado para "audição", dando a entender, séculos depois, que o Surdo-Mudo pode "ouvir", por meio do aparelho auditivo e/ou de cirurgia - como, atualmente, com o implante coclear - e "falar", como o Náo-Surdo-Mudo, por meio da oralizaçáo artificial e antinatural, de acordo com o contexto "imaginário". Além do seu "entre-lugar" estar inserido no processo de transação cultural ao longo da história, e é justamente a situação da discussão da transação e do pensamentonpositivista, colonialista e estruturalista. A essência da identidade e da subjetividade foram submetidas à abolição da designação "Surdo-Mudo" em prol da "imaginária"^ oportunidade de se igualar com o "imaginário" de Não-Surdo-Mudo no mundo da industrialização e da tecnologia. Entretanto, o conceito "Surdo-Mudo" permaneceu e ainda permanece na fronteira identitária, por dois fatores comumente marcados : a modalidade visual (ou gesto visual) e a ausência da utilizaçáo do uso da

\footnotetext{
${ }^{3}$ Termo da autoria de Derrida (1993) que designa o privilégio da fala sobre a escrita em que se assenta. Toda a tradição metafísica domina o pensamento ocidental.

4"Imaginária" no sentido de estarem no mesmo lugar, mas com "perspectivas diferentes", e de modo como ele "interpreta" as pessoas Surdas. A realidade das pessoas surdas não é diferente, mas se olharmos do outro foca na "falta de audiçâo" dos Surdos, então eles se limitam somente ao lado negativo de cada coisa que possa ter acontecido para que alguém se tornar surdo. Um olhar que náo se importa com a realidade em que os surdos estáo agora.
} 
modalidade oral ${ }^{5}$.

Antes de tudo, o conceito "Surdo-Mudo" já vem desde o tempo da constituição de "naçáo" ou de "povo". Esse conceito de "naçáo", como diz Anderson (1983 apud SOUZA, 2007), representa "a noçáo da nação enquanto comunidade imaginada", elaborada pela concepçáo ouvintista. $\mathrm{O}$ conceito "imaginário", na perspectiva de G. Durand (1997) e de C. G. Jung (1911), seria como universal, simbólico, imaginativo e dinâmico através dos discursos ideológicos do imaginário, mas com a característica da univocidade e sem a multivocidade deste. $\mathrm{O}$ imaginário, nessa concepção, representaria o fundamento não cognitivo da representaçáo social, articulando sua causalidade figurativa e a sua face simbólica. Portanto, a "imaginação" individual e coletiva ouvintista nunca se aplicava à comunidade, ao povo e à nação do Surdo-Mudo por ele existir desde quando os homens começaram a se comunicar uns com os outros, antes da fala, e nunca foi "imaginada" como pensavam os positivistas. Como diz o professor Marcos Rocha (2006), da disciplina Linguística Geral da UFSC: "a fala é a invenção do homem" e "os sinais também são as invenções do homem”. Isso supóe que os sinais e os gestos já existiam na pré-história antes da invenção do fogo e dos objetos rudimentares feitos pelos homens. Quando os homens pré-históricos inventaram a "fala" e o seu processo; quando os pesquisadores, por meio da concepção "fonocentrista", privilegiaram e focalizaram a "fala", excluíram os gestos, as pinturas e as comunicaçóes dos hominídeos da pré-história. Ou seja, pelo desconhecimento total da comunicação primitiva, ocorreram inúmeras separaçóes entre os seres humanos.

No decorrer deste texto, pretendemos apresentar o desenvolvimento e o processo de surgimento e apagamento da designação "Surdo-Mudo".

\section{De onde vem a palavra "Surdo-Mudo"}

Historicamente, a criação da denominação "Surdo-Mudo", como palavra composta, surgiu durante a criação dos Direitos Civis no tempo do Imperador Justiniano. Acrescentamos que antes da designaçáo Surdo-Mudo se referir aos sujeitos que não ouviam, bastavam as designaçôes "Surdo" ou "Mudo", em funçáo do que se conhecia naquela época. É interessante notar que a designação Surdo-Mudo sequer foi registrada pelos cientistas ou pesquisadores como uma forma para designar os homídios da pré-histórica

${ }^{5} \mathrm{Na}$ concepção cultural dos Surdos, isso quer dizer: ausência da "fala" e nâo da língua "oral" ou "falada" que são modalidades sonoras. São duas distinçôes diferentes. 
que, antes da invenção da "fala", já se comunicavam com as mãos, como apresentado no filme "A Guerra do Fogo".

A narrativa fílmica em questão trata da rivalidade entre dois grupos: um que cultuava o fogo como divindade sobrenatural e outro que dominava a tecnologia de fazer o fogo. Com o domínio da tecnologia e do instrumento do fogo, os gestos já apresentavam importância na comunicação, como diz Rousseau e Herder, nos seus dois ensaios do livro "On the Origin of Language". Os autores afirmam que o gesto surgiu como primeira manifestação mais fácil da linguagem humana, que mostra a expressão pessoal de paixão, raiva, ódio, poder, amor e prazer:

Although the language of gesture and spoken language are equally natural, still the first is easier and depends less upon conventions. For more things affect our eyes than our ears. Also, visual forms are more varied than sounds, and more expressive, saying more in less time.....Our gestures merely indicate our natural unrest (ROUSSEAU; HERDER, 1996, p. 6) ${ }^{6}$.

A maioria dos filósofos naquele tempo, a exemplo de Rosseau e Herder, através de suas reflexôes, registraram que: "Nossos gestos meramente indicam nossa inquietação natural.” (1996, p. 6). Esse foi um importante ponto de partida para várias pesquisas avançadas na área linguística de língua de sinais juntamente com as várias interfaces de outras áreas, como psicologia, antropologia e muitas outras. A inquietação é uma das características do instrumento particular, que consiste em "querer se comunicar", e da ansiedade emocional como característica do Surdo-Mudo de comunicar ou náo. Os gestos influenciam de modo natural e comunicativo, de acordo com o significado do "real" e da crença daquela época.

Voltando ao filme "A Guerra do Fogo", o segundo grupo que dominava a tecnologia apresenta uma comunicação mais convencional, com um maior número de sons articulados, por conta de/como resultado de fatores que influenciaram: evolução da locomoção como bípede, criação e manipulação dos instrumentos, elementos culturais, habitação, ritos e crenças. $\mathrm{O}$ primeiro grupo não se apresentava como o segundo, mas isso não quer dizer que estivessem em desvantagem, em relação ao uso da língua

${ }^{6}$ Tradução nossa: Embora o gesto e a língua falada sejam igualmente naturais, a primeira é ainda mais fácil e depende menos das convençóes. Por mais coisas que afete nossos olhos do que nossos ouvidos. Também, as formas visuais são mais variadas do que sons, e mais expressiva, dizendo mais em menos tempo......Nossos gestos meramente são indicados como inquietação natural. 
e da comunicação, se presume que utilizavam. Assim, acreditamos que os gestos vieram, primeiramente, como forma comunicacional e não podem ser desvinculados de uma identidade e de uma funçáo instrumental da comunicação.

Ferdinand de Saussure argumenta que

a ausência de uma palavra [ou seja, o nosso grunhido ou dos gestos] prova de que a civilização primitiva ignorava a coisa designada por essa palavra, trata-se de um erro. Dessarte, a palavra "arar" falta nos idiomas asiáticos; isso, porém, não significa que tal ocupação fosse desconhecida no princípio; o arar pode muito bem ter caído em desuso ou ter sido levado a cabo através de outros procedimentos, designados por outras palavras (1977, p. 263).

Isso mostra que as palavras, os sons e os instrumentos da comunicação provêm da identidade cultural e não da palavra em si, mas sim de uma convençáo coletiva. Muitos séculos depois dos hominídeos pré-históricos, emergi uma vaga designação das palavras "Surdo" e "Mudo", até se unirem numa palavra composta: "Surdo-Mudo"

Sócrates, durante uma conversa com Hermógenes sobre a língua dos "Mudos", demonstrou, novamente, a existência de gestos no processo comunicacional. As citaçóes abaixo foram extraídas durante a aula assistida em meu estágio em 2006 na Gallaudet University, com o Dr. Dirksen Bauman, professor do Departamento dos Estudos Surdos \& ASL, na disciplina: "Filosofia e Língua". A citação do trecho do capítulo "Crátilo" de Platão (Diálogos, subtítulo 422 e - 423 b, 2001, p. 199), que se segue, nos faz pensar sobre as denominaçóes "Surdo" e "Mudo" no tempo da Grécia (a hipótese é que, seja o que for, o significado do diálogo com o Hermógenes que pode ser pelo apelido carinhoso ou denominar "alguém" que não oraliza):

SÓCRATES: Muito bem. E os primitivos, os que não têm outro nome como substrato, de que modo farão ver, com a maior clareza possivel, a realidade, se terão de ser nomes?Responde-me ao seguinte: Se não tivéssemos nem voz nem língua, e quiséssemos mostrar as coisas uns aos outros, não procuraríamos fazer como os mudos, indicando-as com as mãos, a cabeça e todo o corpo?

HERMÓGENES: Não haveria outro jeito, Sócrates. SÓCRATES: A meu parecer, se fosse preciso indicar alguma coisa elevada ou leve, levantaríamos as mãos para o céu, para imitar a própria natureza da coisa; se fosse algo pesado e baixo, para o chão é que as estendêramos, e no caso de querermos indicar um cavalo, bem sabes que procurariamos deixar nosso corpo semelhante ao deles, tanto quanto possivel, assim na forma como no gesto. 
HERMÓGENES: Acho que forçosamente é como dizes. SÓCRATES: E uma vez que queremos expressar-nos com a voz, a língua e a boca, não poderemos exprimir o que quer que seja por esse meio, se procurarmos imitar seja o que for? HERMÓGENES: Necessariamente, penso.

SÓCRATES: O nome, portanto, como parece, é a imitação vocal da coisa imitada, indicando quem imita, por meio da voz, aquilo mesmo que imita.

HERMÓGENES: É o que penso.

É um caso interessante refletir que a "voz" imita o "nome" das "coisas" no discurso filosófico entre Sócrates e Hermógenes. Isso fica dito que a "voz" é uma reprodução ${ }^{7}$ das "coisas" e a hipótese de que o "gesto" ainda continua imune às críticas e complexos filosóficos. É lamentável que os sofistas (menos o Sócrates) não tenham reconhecido em curto tempo a importância do "gesto" que é uma base para o desenvolvimento de alguns elementos da linguagem (emblema). Embora não seja um sistema linguístico completo, os sistemas de sinais produzidos ou de "sinais caseiros" daquela época apresentam propriedades essenciais das línguas humanas e de comunicação do "Surdo-Mudo". Apesar de os dois filósofos não chegarem a nenhuma conclusão, a história da denominaçáo "surdo-mudo" podia ter um debate sobre a sua existência e sua relação com a sociedade.

Isso prova que na escrita da tradução da Escritura dos Velhos Testamentos em Levítico (Antigo Testamento, 19:14), a denominação "Surdo" ou "Mudo", foi reproduzida nas traduçóes ao longo de trezentos anos depois de sua escrita. Esta denominação já era utilizada nos tempos mais remotos, como segue esta citaçáo: "Não amaldiçoarás ao surdo, nem porás tropeço diante do cego; mas terás temor do teu Deus. Eu sou o Senhor" (Levítico 19:14).

$\mathrm{Na}$ Bíblia, a reprodução da terminologia acontece quando o apóstolo de Jesus Cristo, Marcos (Mc 7.32-35), presenciou a cura de um "Surdo" ou "Mudo", conforme as citaçôes:

Trouxeram-lhe um surdo que mal podia falar"; "suplicaram-lhe que lhe impusesse as mãos sobre ele. (Mc 7.32)

Jesus, tirando-o da multidão, à parte, pôs- lhe os dedos nos ouvidos e lhe tocou a língua com saliva; (34) depois, erguendo os olhos ao céu, suspirou e disse: Efatá!, que quer dizer: Abre-te! (35) Abriram- se-lhe os ouvidos, e logo se lhe soltou o empecilho da língua, e falava desembaraçadamente. (Mc 7.34-35)

${ }^{7}$ Derrida (1993) inventou a palavra desconstrução, atacando o logocentrismo ocidental, alegando ser a razáo o aprisionamento do homem. 
O profeta de Deus, Isaías (Is 35, 4-6) afirma/expóe/declara que:

Tende coragem, não temais. Aí está o vosso Deus; vem para fazer justiça e dar a recompensa; Ele próprio vem salvar-vos. Entáo se abrirão os olhos dos cegos e se desimpedirão os ouvidos dos surdos; entáo o coxo saltará como um veado e a língua do mudo cantará de alegria

Não podemos checar a veracidade da designação "Surdo" ou "Mudo" ou "Surdo- Mudo" na Bíblia, tanto como Antigo ou Novo Testamento, porque traduçôes da Bíblia para língua grega e outras línguas, no caso da romana, demoraram quase trezentos anos para serem feitas.

No tempo do Rei Constantino, o Grande, em 325 D.C., na cidade de Constantinopla se

\begin{abstract}
convocou o Concílio de Nicéia, quando estava em crise romana com a ameaça da divisáo dos bispos, para proclamar o Dogma da Divindade de Jesus Cristo, com a finalidade de ganhar prestígio político, transformando a prática dos tradicionais do culto pagão em romano e controle entre os bispos das cidades onde foram designados para controlar e influência em nome dele. Na proclamação do Dogma, ou seja, a "verdade" revelada, um termo que não estava contido nas escrituras (em nenhuma passagem, o Novo ou o Antigo Testamento) (FO et all., 2005, p. 41).
\end{abstract}

Nada se pode supor que as versóes bíblicas podem ser originais ou não. Na suposição de que se trata de uma "lenda" bíblica ou da demonstração histórica do homem mais importante de todos os tempos: Jesus Cristo. $\mathrm{Ou}$ do uso do instrumento bíblico como imposição e subordinação política daquela época. As citaçôes bíblicas tinham muitas metáforas que eram incompreendidas para o povo daquela época. Atualmente, muitos religiosos tentam traduzir de acordo com as metáforas das frases de Jesus Cristo, querendo esclarecer que a palavra "Surdo" significaaquele que "tem resistência para ouvir as prelaçóes da Boa-Vinda" de Jesus Cristo, sendo também que o Surdo-Mudo por não divulgar as Boas Novas do mesmo e também dos "propósitos de Deus são sempre de bem, mesmo que estes se dêem por situaçôes adversas à vida, contrárias ao que se espera de Deus." (KUCHENBECKER, 2006, p. 80).

O registro da denominação da palavra composta "Surdo-Mudo" começou no século VI D.C, quando o Imperador Justiniano criou os 
Direitos Civis. Já existiam cinco categorias que classificavam os surdosmudos em: surdo-mudez natural, surdo-mudez adquirida, surdez natural, surdez adquirida e mudez natural ou adquirida (KUCHENBECKER, 2006). Pela consciência humana de um, foi uma denominação que dá mais sentido a esse significado; e para inconsciência humana do outro, a denominação passou a ser um estigma e estereótipo social e educacional com interpretações errôneas sobre essa designaçáo. O significado passou a ter sentido no significante, como escreve Souza (2007, p. 10):

Ao invés da visão fixa da língua e cultura como texto fixo, produto de regras pré-estabelecidas e fixas, Howard-Malverde propóe uma visão dinâmica, emergente e performativa que vê a língua e a cultura como encenação (enactement) dialógica onde os "textos" (não mais estáticos) não apenas ocorrem em contexto, mas também, mais importante, enquanto contexto. Assim cada ação ou realização cultural e lingüística é constituída por e constitui o contexto. Além do dinamismo, essa visão recupera o conceito de agência em açôes culturais onde membros de uma cultura ou língua não apenas reproduzem normas e códigos, mas também os transformam.

No tempo do Santo Agostinho, seguiu-se a crença bíblica de que o Surdo-Mudo podia ser salvo do pecado através de sinais. E para atrair os Surdos-Mudos, cujos pais católicos não tinham esperança e estavam perdendo a fé sobre eles, Santo Agostinho iniciou uma campanha para educar os Surdos-Mudos por meio de instrução religiosa para preservar a fé e moral e também para fazê-los frequentar as missas dominicais.

Charles Michel de L'Epée, comumente, chamado de Abbé de L'Epée (1712- 1789) começou a ensinar duas irmãs surdas. Com o desenvolvimento extraordinário da comunicação entre as duas irmãs e de seus pupilos que também eram surdos-mudos, fundou, em 1760, a primeira escola denominada de Institution Nationale des Sourds-Muets, atual Institut National de Jeunes Sourds de Paris (INJS).

Com o sucesso na formação de vários professores Surdos-Mudos, passou-se a criar muitas instituiçóes em outros países com a mesma designação, assim como: Madrid's Royal School for Deaf Mutes (em 1805, Madri - Espanha), The State Deaf Mute Institute (em 1899, Arkansas EUA), Northern New York Institution for Deaf Mutes (em 1907, Malone, Franklin County - EUA), The Arkansas Deaf Mute Institute (em 1869, 
Arkansas - EUA), Institute for Deaf-Mutes (Estocolmo - União Européia), Ohio Institute for the Deaf and Dumb (Ohio - EUA), Deaf and Mute Institute (em 1870, Oregon - EUA), Texas Institute for Deaf, Mute, and Blind Colored Youth (em 1887, Texas - EUA), New York Institute for the Deaf-Mute (New York - EUA), The Royal Institute for the Deaf and Mute (Copenhagen Dinamarca), Institute for the Deaf-Mute (Warsaw - Polônia) e muitas outras.

Em 1817, nos Estados Unidos, foi fundada a primeira escola pública para Surdos-Mudos em Hartford, Connecticut, denominada de The Connecticut for the Education and Instruction of the Deaf and Dumb Persons. Mais tarde, em 1864, o Congresso americano aprovou a primeira faculdade para Surdos-Mudos: a National Deaf-Mute College, que, atualmente, se chama Gallaudet University, em homenagem ao filho de Thomas Gallaudet, Edward Gallaudet, fundador da Universidade.

Há também a designação "Silencioso" para designar os SurdosMudos, como, por exemplo, no fim do ano de 1890 e metade do século 20, com o Jornal Worker Silent que era um jornal nacional muito popular na comunidade Surda-Muda nos Estados Unidos. Originalmente, foi publicado em fevereiro de 1888, como Jornal Deaf-Mute e foi modificado em setembro do mesmo ano, para Worker Silent. A publicação cessou em 1929. As coleçôes de 1888 a 1929 desse jornal estão arquivadas na Gallaudet University no formato digital, disponível para a pesquisa pública no World Wide Web ${ }^{8}$. Em 1760, depois da fundação do primeiro Instituto de Jovens Surdos-Mudos de Paris, em Paris, várias escolas e instituiçôes europeias e americanas separaram as instituiçóes de "Surdos-Mudos" e "Surdos-Cegos". Com a separação, do "Instituto Columbia para Instrução de Surdos-Mudos e de Cegos", em 1857, os cegos criaram a sua própria escola. O Instituto para abrigar os Surdos-Mudos, em 1911, passou a ser denominado Instituto Columbia para Surdos.

Diderot (1993, p. 11), antes de publicar sua enciclopédia, publicou o livro "Carta sobre os surdos-mudos para uso dos que ouvem e falam" (1751) divergindo das bases teóricas de professor Abade Charles Batteux sobre "a origem das linguas, a linguagem gestual dos surdos-mudos, a unidade (ou simultaneidade) de pensamento e percepção da formação do juizo...”. Ess e livro foi publicado antes da criaçáo da primeira escola de surdos-mudos em Paris, portanto ele nos informa que haviam surdos-mudos nas redondezas de Paris, e narra a seguinte passagem:

${ }^{8}$ http://www.aladin.wrlc.org/gsdl/collect/gasw/gasw.shtml. Acesso em 2005. 
Um dia estava eu jogando xadrez, e o mudo me via jogar. Meu adversário deixou-me numa situaçáo embaraçosa; o mudo percebeu isso muito bem e, acreditando estar perdida a partida, fechou os olhos, inclinou a cabeça e deixou cair os braços, sinais por meio dos quais me anunciou que me tomava por morto, ou em xeque. Notai, aliás, como é metafórica a língua dos gestos (DIDEROT, 1993, p. 25).

No Congresso de Miláo, na Itália, nos dias 6 a 11 de setembro de 1880, fez-se as oitos resoluções para Surdo-Mudo (Deaf-Mute), Surdo (Deaf) e Silencioso (Dumb). A partir de então, com a implantação da filosofia Oral Pura, foi modificada a designação de "Surdos-Mudos" para "Surdos", como definição correta no trabalho clínico terapêutico para fazer os Surdos falarem e ser normalizados como os Não-Surdos. Para refletir melhor, o Congresso de Milão pode ser denominado de circo popular para definir o que é melhor para Surdos-Mudos, como mostra o exemplo Montaigne, no seu essais (ensaios) sobre o índio brasileiro:

[...] à nossa "grande e ponderosa mãe natureza" para refletir sobre esses homens "vizinhos de sua ingenuidade original". Essas afirmaçóes explicam que a história das ideias tenham retido a temática de bom selvage, que se tornará, no Ocidente, uma referência paradigmática à origem de uma verdadeira "revolução moral" (CARELLI, 1994, p. 45).

Sanchez (1990, p. 31), nos documentos de Perelló (1978, apud SANCHEZ 1990), dita que o Aristóteles declara que "había gente que nacía sorda, y que los sordos de nacimiento no lograban hablar normalmente, por lo cual se expresaban por señas"'. Os documentos de Perelló (apud SANCHEZ, 1990) confirmam o número de surdos-mudos na Antiguidade, assim também, Aristóteles afirmava: "los que por nacimiento son mudos também son sordos: ellos pueden dar vos, más no pueden hablar palabra alguna" ${ }^{10}$. É de suposição que o Surdo-Mudo pode falar por "sinais", mas não é necessariamente e/ou obrigatoriamente aprender a "oralizar". O Surdo-Mudo que não oraliza, pode e continua sendo denominado ou designado por Surdo-Mudo. Já o Surdo-Mudo que emite voz "distoante"11

\footnotetext{
9 Tradução nossa: Havia gente que nascia surda e que os surdos de nascimento não conseguiam falar normalmente, mas se expressavam por sinais.

10 Tradução nossa: Os que por nascimento são mudos também são surdos: eles podem dar vozes, mas não podem falar palavra alguma.

${ }^{11}$ A voz distoante do Surdo-Mudo, em via e/ou processo da Oralização, é aquele que difere
} 
e distinto do Náo-Surdo-Mudo pode ser denominado como Surdo-Mudo. No entanto, não se pode mais supor que o Surdo-Mudo náo consiga emitir a voz, como muitos pensam hoje em dia, associando à patologia da mudez. $\mathrm{O}$ Surdo-Mudo é aquele que pode emitir a voz, mas não tanto ou igual como a voz do Não-Surdo-Mudo. A voz possui uma característica tonal diferente tanto para o Surdo-Mudo, como para o Não-Surdo-Mudo.

Diferentemente do conceito em português, a designação "SurdoMudo", nos Estados Unidos, era Deaf-Dumb. Culturalmente, o conceito era ambíguo. Inicialmente, Dumb quer dizer "falta de habilidade para falar" e não "ausência de inteligência". Com a evolução do conceito, a visão logocêntrica priorizou sempre o significado em detrimento da palavra, dando a depreciação errônea para essas designaçóes, o que náo condiz com nenhum pensamento e significado para a comunidade Surda-Muda. Com a ideia de desconstruçáo proposta por Derrida (1993), o foco se volta ao significado. Mostrando o exemplo do neologismo que aglutina a palavra francesa différence (diferença) e o verbo différer (diferir, adiar). Portanto, é possível desconstruir, no sentido de perpetuar essa terminologia "politicamente correta" e "positiva" do conceito e o seu significado "Surdo-Mudo" desta terminologia, que de acordo com Souza (2007, 2010): "Assim cada ação ou realização cultural e linguística é constituída por e constitui o contexto". O significado depreciativo necessita ser retirado do contexto social e educacional para retornar como o significante original que foi depreciativo, perdido, apagado e submetido nos significados dos dominantes.

Acontece o mesmo com a designaçáo "Dumb" que veio da língua inglesa e foi incorporado na língua norte-americana. Esta significa "Silencioso", mas na significaçáo depreciativa oriental também se pode dizer como "idiota" ou "insano" de acordo com a designação contextual, mas não para a comunidade Surda-Muda. A depreciaçáo passou a assimilar contextualmente com a imagem do Surdo-Mudo, como pessoa incapaz, muda, coitada, como diz Thoma (1998, p. 125): "a constituição imaginária a partir das crenças e valores individuais e o tratamento social dado ao surdo a partir desta constituição.”.

No Brasil, a história da terminologia "Surdo-Mudo" começou em 26 de setembro de 1857, quando o Professor e Ex-Diretor E. Huet, com o apoio do Imperador Dom Pedro II, fundou o Imperial Instituto de Surdos-

da voz Não-Surdo-Mudo. Não é "limpa" e nem cristalina. Costuma provocar aos outros NãoSurdo-Mudo a indagar, pedir repetência e estranhamento da voz do Surdo-Mudo. Isto costuma constranger os Surdos-Mudos e para satisfazê-lo, passam a aceitar a imposiçáo deles, como o uso do aparelho auditivo e do treinamento da fala. 
Mudos. Em 6 de junho de 1957, passou para a denominação de Instituto Nacional de Educação de Surdos, com a criação do Centro de Logopedia do Instituto, o primeiro do Brasil. Isso se deu devido a criação do curso de Logopedia que formou os primeiros professores para ministrar a aula juntamente com a terapia da "fala" sem conteúdo educacional. O trabalho era voltado para a aquisição da linguagem, da "fala". Portanto, para prestigiar a promoção humana dos Surdos-Mudos na "fala", precisou-se mudar o nome da instituição. Como escreve Carelli (1994, p. 26):

A passagem do tipo de estereótipo na opiniấo fortifica os mitos tomados na acepção contemporânea de "imagens simplificados exercendo uma potente fascinação sobre a imaginação coletiva”.

A Associação Alvorada Congregadora dos Surdos, fundada em 1953, que sofreu a influência do "oralismo", era, antes, denominada de Associação Alvorada, Congregadora dos Surdos Falantes, A té no estatuto era especificado Surdo-Mudo em via da oralização como Surdo-Falante, como mostram as Figuras 4 e 5.

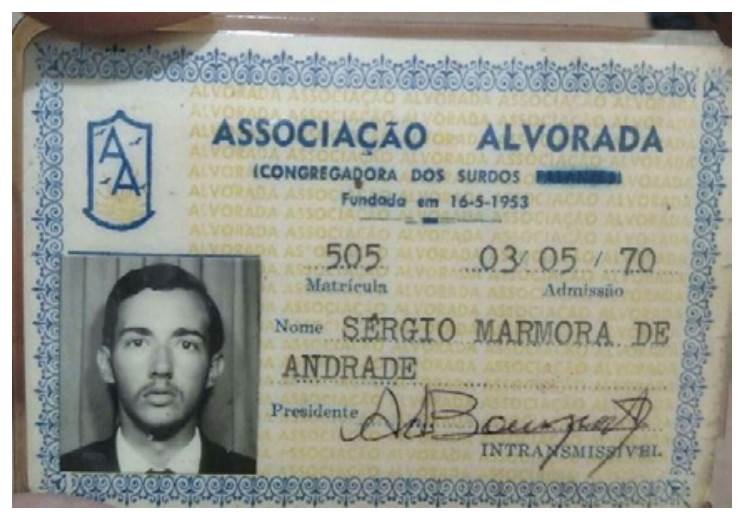

Figura 4

Foto cedida pelo Surdo-Mudo Sérgio Marmora de Andrade 


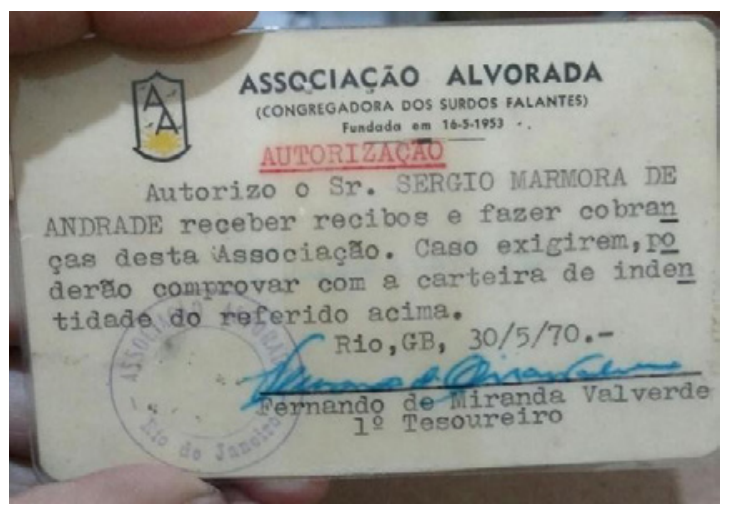

Figura 5

Foto cedida pelo Surdo-Mudo Sérgio Marmora de Andrade

Cada aluno Surdo-Mudo do ex-internato no Instituto Nacional de Surdo-Mudo voltava para suas cidades de origem nas férias ou da formação escolar, criava suas associaçóes com a denominação simbolicamente e culturalmente carregada como: Associação dos Surdos-Mudos de São Paulo, em São Paulo; Federação Carioca dos Surdos Mudos, no Rio de Janeiro; Associação dos Surdos Mudos de Porto Alegre, em Porto Alegre; Sociedade dos Surdos Mudos do Rio Grande do Sul, igualmente, em Porto Alegre; Associação de Surdos-Mudos de Minas Gerais, em Belo Horizonte; Associação dos Surdos Mudos de Uberlândia, em Uberlândia (a associação utiliza este nome até hoje). Em outros países também encontramos exemplos da criação dessas associaçóes: Associacion dos Sordosmudos Ayuda Mutua, em Buenos Aires (Argentina), Associacion de Sordomudos de Chile (Chile), Organización Nacional de Sordos Mudos (El Biar - Argélia), All Pakistan Deaf and Dumb (Lahore - Paquistão), Asociación Pro-Educación de los SordoMudos Inc. (Santo Domingo - República Dominicana), Turkish National Federation of the Deaf and Dumb (Istambul - Turquia), Associacion de Sordomudos del Uruguay (Montevideo - Uruguay) e muitos outros.

Em 24 de maio de 1913, escreve o autor Bacellar:

um pequeno grupo de surdos mudos reunido no Instituto Central do Povo (um departamento para surdos-mudos com fins escolares e extra-escolares, fundado pelo Dr. Brasil Silvado na Associação Protectora dos Surdos Mudos), fundou a primeira Associação Brasileira de Surdos Mudos. Em dezembro de 
1914, apareceu o primeiro número do Euphphata, jornal mensal, sustentado pelo Instituto Central do Povo. Infelizmente esta publicação teve vida ephemera, pois em julho de 1916 sahiu á luz o seu último número (1925, p. 9).

Isso mostra que os Surdos-Mudos, como pessoas que não usam a oralização daquela época, demonstraram a competência linguística e intelectual para criar um jornal com a modalidade escrita da segunda língua: portuguesa. São as habilidades que assemelham e utilizados em outros países antes do "negro" Congresso de Miláo, de 1880.

\section{3. "Surdo-Mudo" ou "Surdo"}

Hoje, há várias concepçôes, dogmas, crenças, paradigmas, estereótipos, estigma no contexto da vida social e humana nos ensinos das escolas especiais, inclusivas ou regulares. Esse tema tornou-se um assunto controverso devido à homogeneidade e normalização ${ }^{12}$ das pessoas SurdasMudas, dos colonizadores e seus hibridismos, carregado de sua própria cultura nacional. As mesmas acabam desconhecendo o tema da naçáo, como é o povo Surdo-Mudo, até no contexto do significado "Surdo-Mudo". A hipótese das alunas participantes da pós-graduação é de como enfrentá-lo se existe um outro "povo" ou "naçáo" diferentemente deles? De onde eles surgiram, do "nada"? Por isso este tema serve com o suporte da base para denotar esse mito da concepção da homogeneidade.

Recordo-me da sala de aula do GES (Grupo de Estudos Surdos), em 2005, na disciplina de Estudos Surdos. Ali se reuniam diversos estudantes de pós-graduação oriundos de diversos estados do Brasil: Paraná, Rio Grande do Sul, Goiás, Rio de Janeiro e Santa Catarina. Na presente sala, havia mais Surdos-Mudos do que Não-Surdos-Mudos, com identidade híbrida e flutuante. A professora Gladis Perlin estava explanando sobre a denominação do significado para determinar a identidade dos Surdos-Mudos e dos usuários da língua de sinais para diferenciar dos Náo-Surdos-Mudos. Este exemplo serve para especificar a diferença dos usuários da língua de sinais: os Não-Surdos-Mudos podem ser usuários de língua de sinais, como usuários bilíngues, mas com identidade não muito híbrida e de transição na fronteira da cultura surda-muda. $\mathrm{Na}$ aula, houve uma interação, uma dinâmica

${ }^{12}$ Larrosa e Peres de Lara (1998), acrescentam: "para classificar e excluir pessoas que não são como nós, e para enquadrá-las em aparatos pedagógicos, assistenciais ou terapêuticos”. 
de modo que com o uso do quadro negro pudessem ser colocadas várias designaçóes identitárias como Surdo, Surdista, etc. Quando chegou a minha vez de colocar a denominação de "Surdo-Mudo", houve várias indagaçóes e expressôes faciais e de desdém. Um participante e uma ex-aluna do estado, que é a terra de Cora Coralina e do filme "Dois Filhos de Francisco", disse assim: "Ah! Não....como é que a sociedade vai pensar e me ver assim? Ah! Não...” (2005).

O primeiro pensamento que me ocorreu foi o fato de que se está estudando na disciplina de Estudos Surdos: como é que pode discordar da linha de pensamento da comunidade e do povo Surdo-Mudo, do seu processo histórico e do "apagamento" imposta pela sociedade, mesmo como Surda Híbrida e sinalizante de língua de sinais brasileira? Conclui existir ainda uma resistência de "não-aceitação" da denominação pejorativa, por desconhecimento e aprofundamento da pesquisa pela maioria.

Também a noção da nação, de comunidade ou povo Surdo-Mudo, atualmente, é um conceito imaginário para todos nós, os Surdos-Mudos com múltiplas identidades: surda, híbrida, de transição, incompleta e flutuante, devido o poder do "ouvintismo"13 que exerce sobre os SurdosMudos, tornando o conceito de Surdo-Mudo um conceito depreciativo e estereotipado. Com o avanço da pesquisa da aluna de pós-graduação e hoje professora da UFSC, Dra. Karin Strobel, foi levantado os significados de "naçáo", "povo" e "comunidade" Surda-Muda para desmitificar o equívoco da concepção ouvintista.

Bauman e Briggs, (2003 apud SOUZA, 2007), traçaram, com suas pesquisas, a origem de conceitos de homogeneidade cultural nacional nas raízes da modernidade europeia. Os autores filiam-se, de modo geral, aos modelos elaborados por Herder, na Alemanha, e por Locke, na Inglaterra, a respeito dos conceitos de homogeneidade cultural. Cada povo e sua naçáo, na Europa, tinha a sua comunidade como "maioria linguística" ou "minoria linguística". Estes conceitos de "maioria" e de "minoria" são muito relativos, pois, como afirma Borst, uma "narrativa que explica a multiplicidade das línguas aparece em várias mitologias e teogonias ${ }^{14}$ (apud ECO, 2002, p. 29).

${ }^{13} \mathrm{Da}$ Gladis Perlin: Na qual o ouvinte sempre está em posição de superioridade, estabelecimento de uma relação de poder, de dominação em graus variados onde predomina a hegemonia através do discurso e do saber" (1998, p.58)

${ }^{14}$ Chauí, Marilena: Teogonia é uma palavra composta de gonia e theós, que, em grego, significa: as coisas divinas, os seres divinos, os deuses. A teogonia é, portanto, a narrativa da origem dos deuses, a partir de seus pais e antepassados. Disponível em: http://www.armazem. literario.nom.br/autoresarmazemliterario/eles/martinhocarloshost/filosofia/8_modulo8.htm. 
Mesmo que o "povo" ou "nação" seja minoritária, estes já tinham estes conceitos da superioridade do discurso filosófico e político que representavam sua razão, a referencialidade pura, precisão e consistência no pensamento, uma forma de demonstrar que a primeira língua, no caso da língua de sinais e sua designação "Surdo-Mudo", é um dos atributos que permitem os utentes usarem e refletirem de uma forma pura, clara e rigorosa. O problema se reflete com Montaigne (CARELLI, 1994, p. 45) que no capítulo de "Os canibais" (1580) recusa o lugar comum a propósito dos índios:

Não há nada de bárbaro e de selvagem nesta nação, pelo que me contaram, senão que cada um chama de barbárie aquilo que não faz parte de seus usos; realmente, parece que não temos outra mira da verdade e da razão, a não ser o exemplo e a ideia das opiniốes e usos do país em que estamos.

Através desse mito e da concepção errônea, o uso desse termo no país em que estamos a repercussão das opiniōes formadas atingiram sem precedente a massa popular. A propaganda da FENEIS (Federação Nacional de Educação e Integraçáo dos Surdos), em 1993, objetivou mostrar que o Surdo-Mudo é, genuinamente, um ente capaz, independente, auto-reflexivo e controlador da situaçáo, assim baniu-se a palavra "Mudo" da designação Surdo-Mudo. Acontece o mesmo com a assimilação da ideia pré-concebida em torno desta palavra: associação de Surdo-Mudo como ser incapaz, como se diz W. Aaron Rudner (2007), tradutor e intérprete de ASL ${ }^{15}$ :

Para mim, o termo surdo-mudo é um diagnóstico que define a pessoa surdo [sic] em termos de incapacidade (não ouve, não fala) ao invés da sua identidade cultural, como usuário de uma língua de sinais. Por tanto, nos EUA já descontinuaram o uso de Deaf-Mute e pior Deaf- and-Dumb (dumb significa tanto burro quanto mudo), e passaram a usar apenas "deaf". Dai, após o movimento pelo reconhecimento da cultura Surda, passaram a distinguir entre "deaf" para denominar pessoas com qualquer perda de audição profunda, e "Deaf” para denominar pessoas culturamente Surdas, sendo que em inglês, etnias sempre levam maiúscula (Black para negro, Jewish para judeu, Brazilian para brasileiro, etc.) Embora no âmbito clínico continuem com o "deaf- mute", fora a expressão tem sumido, exceto para pessoas menos esclarecidas. Pessoalmente, reconheço a importância de nomes. Ajudam formar os conceitos com que as pessoas pensam. Devem

Acesso em 2004.

${ }^{15}$ Disponível em: http://www.diariodosurdo.com.br/noticiantiga/noticia37.htm. Acesso em: 2004. 
ser definidos pelas pessoas que LEVAM o rótulo e não por as demais pessoas que não. De outro lado, quando colocamos energia excessiva nesta discussão, acabamos dispersando energia e tirando nossas atençôes de assuntos que devem ser atendidas com mais urgência, como o direito do surdo ao ensino, à língua de sinais, ao intérprete, e em geral, à igualdade.

Isso também conta com a depreciação pejorativa por "sinais" do significado de "Surdo-Mudo", e isso justamente aconteceu na minha conversa com uma Intérprete de Língua de Sinais Brasileira (LIBRAS), que é formada em Educaçáo Especial em uma das faculdades do sul do Brasil. Ela demonstrou que não concordava com o "sinal" para determinar a pessoa como "Surdo-Mudo". Preferia que o sinal fosse com a configuração de máo, em " $R$ " no ouvido, em vez de sinalizar com o dedo indicador que vem da orelha, passando até a boca, conforme a designação da maioria, convencionada pelos Surdos-Mudos. Expliquei à ela que o sinal, que vem da orelha passando à boca, não tem a ver com a "mudez". A maioria dos Surdos-Mudos (dependendo do caso, pois estamos dentro da diversidade surda o que nos impossibilita de delimitar quantitativamente!!!!) não oralizam e nunca oralizaram quando sinalizavam. Daí esta denominação que é correta para todos nós.

$\mathrm{Na}$ pesquisa para o presente artigo, usamos as abordagens de pesquisa na internet em caráter tanto quantitativo quanto qualitativo. Segundo Batista (2012), estudos quantitativos utilizam-se basicamente das enquetes e questionários virtuais. Sobre as pesquisas qualitativas, Flick (2009) cita a entrevista online, os grupos focais on-line, a observaçáo participante, a etnografia virtual, os estudos de interação e de traços de interação, além da análise de documentos on-line. Ressaltamos , porém, que os procedimentos e a técnicas de pesquisa não se constituem como objetivo desse artigo, uma vez que não pretendemos se aprofundar em cada um deles. No entanto, a pesquisa pretende possibilitar um comparativo entre as técnicas adotadas em pesquisas de campo e as empregadas na internet, apresentando noçôes gerais sobre alguns procedimentos e técnicas de pesquisa. Colocamos a seguinte pergunta: "O que você acha da denominação "Surdo-Mudo"?" na enquete do Orkut $^{16}$ e Yahoo Groups ${ }^{17}$, de abril de 2007 até agosto de 2007, e obtivemos os seguintes resultados:

\footnotetext{
${ }^{16}$ Orkut foi uma rede social filiada ao Google, criada em 24 de janeiro de 2004 e desativada em 30 de setembro de 2014.

${ }^{17}$ Yahoo Grupos é um gerenciador de lista de discussão pertencente ao Yahoo! lançado em 1998.
} 
Daqueles que identificam cultura e identidade Surda $-26 \%$

Faz parte da Identidade Surda - 2\%

Nos Estudos Culturais reflete a identidade Surda - 0\% É pejorativo - 1\%

Não aceito a denominaçáo, prefiro a denominaçáo Surda - 73\% Não sei responder $-1 \%$

A resposta reflete o senso comum da maioria: uma ideia pré-concebida acerca da denominação pejorativa sobre Surdos-Mudos. Ironicamente, em todos os jornais publicados e revistas impressas nos melhores nomes e renomes do Brasil, como Globo, Veja, Jornal do Brasil, Estado de São Paulo, Istoé, etc, mantêm e perpetuam a designação de "Surdos-Mudos". É importante ressaltar que os jornalistas redigem assim, com base na préconcepçáo de que os Surdos-Mudos só sinalizam. Daí a designação bastante positiva.

No Google, encontram-se 94 perguntas sobre Surdo-Mudo e muitos Surdos defendem o nome apropriado "surdo-mudo", mas por que o próprio surdo não o aceita? É um trabalho de longo prazo para fazer aceitá-lo sobre a designação positiva como reconhecimento identitário do sujeito SurdoMudo.

\section{Consideraçóes Finais}

É importante pensar que o uso da denominação "surdo-mudo" tem sido um objeto errôneo e depreciativo, mas também correto para aqueles que mantém seu uso. É impossível sinalizar e falar ao mesmo tempo, como na filosofia da Comunicação Total, que foi fadada ao fracasso, devido a tentativa do uso simultâneo de duas línguas distintas. As pessoas que usam os sinais e não oralizam por que não podem ser denominadas de SurdosMudos?

Para nossa reflexão que pode ser posta em discussão, especialmente na área do ensino de Libras, que é o caminho tortuoso que necessitam urgente a reflexão. Como mostrar a identificação como pessoa Surda no ensino de Libras? Como os alunos nos cursos de Libras irão identificar os professores como seus interlocutores: professor Surdo ou Professor Ouvinte? A Libras é para ser aprendida o que foi ditada oralmente pelos Professores Ouvintes? Quais as estratégias que os Professores devem difundir a Libras dos Surdos-Mudos? Através de que recurso? Pidgin? Bimodalismo? Português Sinalizado? A Libras deve ser minimizada pela falta do domínio 
(vocabulário, fluência, etc.) dos Professores Ouvintes? É muito mais fácil falar no ensino de Libras do que sinalizar? Teorizar a Libras através da fala? Até quando os alunos no ensino de Libras vão dominar a língua dos Surdos que é defendida pela comunidade ou povo Surdo? Até que ponto haverá o respeito linguístico?

A palavra "Mudo" não quer dizer que somos mudos, pelo contrário, somos mudos por que usamos a língua de sinais que é utilizada pelas mãos e não pela boca. Isto faz parte da modalidade viso-gestual e não da modalidade oral-gestual, e a oralidade (e seu uso da fala) inexiste em qualquer ciência da língua. É imprescindível reconhecer a importância de retornar a palavra composta Surda-Muda para resgatar a identidade e cultura de pertencimento e de apropriaçáo da língua de sinais e de diferença em relação aos usuários Náo-Surdos-Mudos, especialmente no ensino de línguas, no caso da Libras, nas universidades e disciplinas de Educação de Surdos como um todo.

Afinal, nós todos temos uma ideologia. Para a ideologia da linguagem de Locke, o povo Surdo-Mudo tem "uma voz numa única língua" (2007, apud SOUZA, p.3) e usa a língua de sinais é como "pensamento claro, direto, puro e reflexivo; ou seja, uma língua desinteressada” (p. 291). Eles têm o resultado de "usar a verdade e eliminar a diferença, propiciando as condiçóes ideais para acessar e usar a verdade, uma vez que tal verdade era única, unitária e universal” (p. 291). Estes conceitos se aplicam na língua de sinais como instrumento da verdade e do uso desinteressado de náo se diferenciar dos outros.

Na Gallaudet University, no Departamento de Estudos Surdos, existe um grupo, como Ben Bahan e Dirksen Bauman, que está fazendo pesquisa e se mobilizando para o retorno do uso da denominaçáo Deaf-Mute, como reconhecimento legítimo da identidade cultural de pertencimento dos Surdos-Mudos.

No Brasil, há pouco tempo, Antonio Campos de Abreu promoveu no Grupo Yahoo um manifesto para a volta da designaçáo Surdo-Mudo como identidade cultural própria que transmite a ideia de pertencimento. Ele escreveu, assim traduzido, cujo texto original se encontra em anexo:

Prazer a todos vocês. Eu estudei a denominação Surdos-Mudos e sei que isso significa que tem identidade própria e natural da comunidade surda. Sempre encontro os surdos nos pontos de encontros e todos sinalizam com uma única e só de língua de sinais. Quem mandou dizer que é pejorativo a denominação de surdos-mudos, isso é coisa de pessoas preconceituosas.... 
Pessoas surdas e ouvintes pensam que é pejorativo a denominação de SurdosMudos e passam a mudar a denominação para surdos, é isso? Isso se deu fato pela influência e aceitaçáo de todos nós porque não tínhamos argumentos sobre a nossa identidade e é isso era natural. Eu náo refletia nada sobre isso. Agora, eu reflito mais, unido a imagem pelo pensamento com a razão. Por que a sociedade ouvinte mandou os surdos a terem esta denominaçáo? Agora a sociedade está mobilizando para acabar as denominaçóes de surdos-mudos ou surdo para colocar com a seguinte denominação de deficiente auditivo. Até hoje a palavra "inclusão" substitui as denominaçôes de "deficientes" ou "especial". Agora a sociedade aceita a implantaçáo LIBRAS (Lingua de Sinais) voltada na comunicação de quem? Não podem chamar surdos ou surdos-mudos? Qual é a preocupação da comunicação deles para com nós? Agora os ouvintes, com os traços do colonialismo, estáo usando a Língua de Sinais e o que acontece com eles? Sabe o por que? Os ouvintes passam a usar a Língua de Sinais, como se fossem os donos da verdade, e passam a ensinar a Língua de Sinais porque os surdos náo sabem ou não souberam dar argumentos. Isso é falta de ética profissional. Isso é tarde, mas, acredito que muitos surdos precisam lutar e para isso, precisam aprender e adquirir muitos conhecimentos nas faculdades e saber usar os argumentos. Tenho esperança que os surdos engajem na luta pela melhoria da educação e conscientização à sociedade. Isso é possível porque os surdos precisam usar a força. Neste momento, o mais importante é ter conhecimento geral (argumento, autoestima, defesa, interaçáo e vários outros). O importante é ter identidade.

Precisa acabar ou eliminar a palavra "dificuldade" ou "difícil" como muitos surdos usam ou pensam. E criticar mais das coisas dos ouvintes com argumentos. MAS VOCÊS precisam desenvolver a sua crítica positiva e para isso precisam estudar na faculdade e mais tarde formar como Mestrado, Doutorado, ou profissional na área da educação de Surdos. Antigamente, os professores oralistas usavam a "fala" nas salas de aula e agora com a nova lei LIBRAS, foi um alívio para todos nós. Não tenho nada contra com os ouvintes. Eles são importantes, isso de fato, para trocar ideias e engajamento das nossas lutas. Eu náo disse que os ouvintes não podem dar aula ou aprender a sinalizar se são os direitos deles também, mas a ética e identidade dos Surdos falam mais alto. Eu estudo História e comparei vários contextos dos ouvintes e dos surdos. Eu tenho opiniáo sobre isso e talvez eu não esteja táo certo e posso errar de vez em quando. Desculpe pelo erro de português ou de letras trocadas, alguém tem liberdade para me corrigir. Muito obrigado. Antonio Campos.

A nova inovação da tecnologia do Surdo-Mudo é o vlogsite (em vez de blog, só que é utilizado vídeo, em vez de comentário por escrito. A resposta por vídeo é gravada como se fosse comentário) da Ella Mae Lentz que escreve sobre a volta da denominação Deaf- Mute:

Por que eu escolhi este tema obsoleta, presumidamente negativa, a denominação "surdo-mudo" neste vlogsite? Este vlog explica as diversas 
razões, mas, no momento em inglês. Primeiro: a tradução literal do sinal comum para SURDO, o dedo indicador que vem da orelha, passando até a boca, é SURDO-MUDO... sim, é o significado original e todos nós temos que dizer que nós somos "surdos-mudos" com muito orgulho...(risos).... Segundo: Para um grupo oprimido, temos o poder para recuperar estes termos negativos sobre este grupo. O Queer e o Dyke (termos pejorativos que designavam gay e lésbicas, criados pelos dominantes) cujos termos eram pejorativos foram recuperados por meio de nossos poderes. Eu tenho visto recentemente que alguns povos surdos começaram a recuperar a terminologia "Surdo-Mudo"... mas somente nós podemos usar esta denominação. Não é para o público em geral ou aos grupos profissionais que continuam não entendendo sobre nós ou nos olham com desprezo... então eles ainda não sabem usar corretamente a terminologia "surdo-mudo".....

Apesar da história da denominação ser interessante, defendemos, de qualquer forma, a restituição do termo "Surdo-Mudo" por sabermos que essa pode ser uma das estratégias de resistência e afirmação do pertencimento linguístico da pessoa Surda a uma comunidade sinalizante. Uma estratégia de fazer mudar a direção das forças, de fazer os "outros" aprenderem a se comunicar em Libras, ou por gesto, em vez de forçar os Surdos a "falarem" ou "oralizarem" para serem aceitos.

A denominação "Surdo-Mudo" é um prato cheio de reflexóes quanto a sua utilização de maneira desejável e útil, ou mesmo prazerosa , para aqueles que nunca ouviram voz nenhuma e se sentem bem em não falar. A comunicação verdadeira, para esses sujeitos, é do uso das mãos. Só com os estudos e o engajamento da comunidade, enquanto povo e naçáo Surda-Muda poderemos retornar o que nos foi usurpado, excluído, perdido e estipulado do nosso lugar de origem. Nós nos orgulhamos de ser chamados de Surdos-Mudos ou Surdas-Mudas.

\section{Referências}

ABREU, Antonio Campos. Depoimento sobre a terminologia Surdo-Mudo. Grupo Yahoo. 2007.

ARALDI, Inês. A Carapuça da Discórdia: uma análise dos discursos que emanam de um gesto presidencial. Artigo. Linguagem em (Dis)curso - LemD, Tubarão, v. 5, n. 2, p. 323-335, jan./jun. 2005. Disponível em: <http:// www3.unisul.br/paginas/ensino/pos/linguagem/0502/04.htm>. Acesso em: mar. 2007. 
BACELLAR, Arnaldo de Oliveira. A Surdo Mudez no Brasil. Sáo Paulo. Faculdade de Medicina de São Paulo. 1925. Acervo do INES.

BATISTA, Micheline Dayse Gomes. Pesquisa na internet: consideraçôes metodológicas. Encontro de Ciências Sociais do Norte Nordeste e Pré-Alas do Brasil. $15^{\circ}$. 2012. Teresina-PI. Anais $15^{\circ}$ CISO PRÉ-ALAS DO BRASIL. Teresina-PI: UFPI, 2012. CD-ROM.

BHABHA, Homi K. O local da cultura. Belo Horizonte: UFMG, 2005.

BIBLIA ONLINE. Disponível em: <https://www.bibliaonline.com.br/nvi/ lv/19/14 >. Acesso em: mar. 2020.

CARELLI, Mauro. Culturas Cruzadas: Intercâmbios culturais entre França e Brasil. São Paulo: Papirus, 1994.

DERRIDA, Jacques. A Voz e o Fenômeno: Introdução ao problema do signo na fenomenologia de Husserl. Tradução: Lucy Magalhães. Jorge Zahar Editor: Rio de Janeiro, 1993.

DIDEROT, Denis. Carta sobre os Surdos-Mudos para uso dos que ouvem e falam. São Paulo: Nova Alexandria, 1993.

ECO, Umberto. A busca da língua perfeita. São Paulo: EDUSC, 2002.

FISCHER, Renate; LANE, Harlan (Eds.). Looking Back: A Reader on the History of Deaf Communities and Their Sign Languages. Hamburg: Signum, 1993.

FO, Jacobo; TOMAT, Sergio; MALUCELLI, Laura. O livro negro do cristianismo; dois mil anos de crimes em nome de Deus. Rio de Janeiro: Ediouro, 2005.

FOUCAULT, Michel. Vigiar e Punir: história da violência nas prisóes. Petrópolis: Vozes, 2007.

FLICK, Uwe. A pesquisa qualitativa online: a utilizaçáo da Internet. In: Introdução a pesquisa qualitativa. Porto Alegre: Artmed, 2009. p. 238-253. GUERRA DO FOGO. Jean-Jacques Annaud. França. Canadá. Estados Unidos. 1981. Disponível em: <https://www.youtube.com/watch?v=a-Z7Nmle$\underline{\mathrm{KO} 8}>$. Acesso em: mar. 2020.

KUCHENBECKER, Klaus Ernesto. O trabalho com pessoas surdas numa congregação de ouvintes. 2006. 158 p. Dissertação de Mestrado (Teologia). IEPG, São Leopoldo, 2006.

LABORIT, Emmanuelle. O Voo da Gaivota. São Paulo: Circulo dos Livros, 1994. 
LARROSA, Jorge Bondia; PÉREZ DE LARA, Nuria. Imagens do outro. Petrópolis: Vozes, 1998.

SCHOLZE, Lia. Narrativas de si: o olhar feminino nas histórias de trabalho. In: SOUZA, Elizeu Clementino de. Autobiografias, histórias de vida e formação: pesquisa e ensino. Porto Alegre: EDIPUCRS; Salvador: EDUNEB, 2006. Disponível em: <http://www.entrelinhas.unisinos.br/index.php? $=4 \& s=9 \& a=24>$. Acesso em: mar. 2020.

PERLIN, Gládis. Identidades Surdas. In: SKLIAR, Carlos. A surdez: um olhar sobre as diferenças. Porto Alegre: Medição, 1998.

PLATÃO. Diálogos; Teeteto Crátilo. Belém: UFPA, 2001.

QUADROS, R. M. de. Educação de surdos: a aquisição da linguagem. Porto Alegre: Artes Médicas, 1997.

SÁNCHEZ, Carlos. La increible y triste historia de la sordera. Caracas: Ceprosord, 1990.

SAUSSURE, Ferdinard de. Curso de linguística geral. São Paulo: Cultrix, 1977.

SKLIAR, C. Atualidade da educação bilíngüe para surdos. Porto Alegre: Mediação, 1999.

. Pedagogia (Improvável) da diferença e se o outro não estivesse aí.

Rio de Janeiro: DP\&A, 2003.

SILVA, Tomaz Tadeu da. A produção social da identidade e da diferença. In: (Org.). Identidade e diferença: a perspectiva dos estudos culturais.

Petrópolis: Vozes, 2000.

SOUZA, Lynn Mario T. Menezes. Language, Culture, Multimodality and Dialogic Emergence. Apostila. Seminário de Estudos Culturais. UFSC, 2007.

. Cultura, língua e emergência dialógica. Revista Letras \& Letras, Uberlândia, v. 26, n. 2, p. 289-306, jul./dez. 2010.

THOMA, Adriana da Silva. Surdo: esse "outro" de que fala a mídia. In: SKLIAR, Carlos (Org.). A surdez: um olhar sobre as diferenças. Porto Alegre: Mediação. 1998.

\section{Anexo}

Que prazer com voce entáo eu estudo sim surdos-mudo de 
signifacado identidade natural comunidade de surdos, sempre encontro de Ponto comunicação atraves mãos é sinalizado unico mundo. Quem mandava retirado feio a palavra surdos-mudos, ainda hoje preonceito... Surdos e ouvinte sentido feio a palavra Surdos-Mudos e retira nome bonito perfeitamento surdos é isso? Infleunciação nosso aceitação mas nos falta identidade sangue propria surdos-mudos é isso natural bem. Eu era sem momento refleição nada. Hoje eu penso refleição (razional pesnamento imagem). é isso sociedade ouvinte manda surdos aceitavam razao a palavra etc. porque? Agora Soceidade manda acabado a palavra surdos-mudos e ou surdo e implantava deficiente auditivo etc. ate hoje inclusão e acabar deficientes e ou especial. Agora esta soceidade bonito implantação LIBRAS (Lingua de Sinais) proecupação comunicação com quem? não pode chamar surdos ou surdos-mudos e so dando rpeocupação estimulação comunicação para nos? Agora ouvinte ja colonialismo pegado Lingua de Sinais atual acontecido? sabia; porque Ouvinte sabe dazemndo ensino Libras por ouvintes entáo Ouvinte prefiro ouvinte sabe bem e surdo não, é isso problema falta profissional ou tarde, Mas eu acredito possivel surdos precisar lutado principal conhecimento momento controle interação e mais estudo Faculdade. Eu tenho POSITIVO surdos luta força de hora hoje frente todos atualmente e vão reeconstruir hora. educação e sociedade. Sim possivel surdos precisar força momento importante conhecimento geral (auto controle, estima, defesa, interação entre varios) importante sentimento e identidade. E acabado e eliminação a palavra dificil e assim surdos. E critica etc ouvinte entre varios. MAS VOCES refazer desenvolver força divulgação comunidade dos surdos recomeçar lutado ou profissional ou estudo faculdade ou Mestrado, Doutorado, ou profisisonal. Era Professores mandava falado oralismo parrendido fala. Quando reeconstruido libea surdos aprdade Lei libras, aliviado. Que Outro vez novo ouvinte colonismo a libras e substituito ouvinte sabe bem Libras povo ouvinte atenção ouvinte sinlaizado e não surdo? Porque surdos não esta momento e ou faltado profissional quem ouvinte opiniáo dele. Sim importante ouvinte sinalizado como troca- ideia corresponedncia para comunicação informação conhecimento para surdos. Eu não posso dizedo ouvinte náo pode ensino e ou sinalziado etc... que direito livre. Eu estudo Historia e comparação contexto ouvinte e surdos. Eu posso opiniáo seu todos e talvez eu acertar ou errar . Lamento eu escreve toque letra e ou portugues errado e corrigir nos muito obrigado. 